University of Nebraska - Lincoln

DigitalCommons@University of Nebraska - Lincoln

8-1993

\title{
Nubenocephalus nebraskensis n. gen., n. sp. (Apicomplexa: Actinocephalidae) from Adults of Argia bipunctulata (Odonata: Zygoptera)
}

Richard E. Clopton

Peru State University, RClopton@peru.edu

Tamara J. Percival Cook

Texas A\&M University, tcook@shsu.edu

John J. Janovy Jr.

University of Nebraska - Lincoln, jjanovy1@unl.edu

Follow this and additional works at: https://digitalcommons.unl.edu/bioscijanovy

Part of the Parasitology Commons

Clopton, Richard E.; Percival Cook, Tamara J.; and Janovy, John J. Jr., "Nubenocephalus nebraskensis n. gen., n. sp. (Apicomplexa: Actinocephalidae) from Adults of Argia bipunctulata (Odonata: Zygoptera)" (1993). John Janovy Publications. 15.

https://digitalcommons.unl.edu/bioscijanovy/15

This Article is brought to you for free and open access by the Papers in the Biological Sciences at DigitalCommons@University of Nebraska - Lincoln. It has been accepted for inclusion in John Janovy Publications by an authorized administrator of DigitalCommons@University of Nebraska - Lincoln. 


\title{
NUBENOCEPHALUS NEBRASKENSIS N. GEN., N. SP. (APICOMPLEXA: ACTINOCEPHALIDAE) FROM ADULTS OF ARGIA BIPUNCTULATA (ODONATA: ZYGOPTERA)
}

\author{
R. E. Clopton, T. J. Percival, and J. Janovy, Jr. \\ School of Biological Sciences, University of Nebraska, Lincoln, Nebraska 68588-0118
}

ABSTRACT: Nubenocephalus nebraskensis n. gen., n. sp. (Apicomplexa: Actinocephalidae) is described from trophozoites, sporonts, gamonts, and oocysts collected from adult Argia bipunctulata (Odonata: Zygoptera). The new genus is distinguished from existing acanthosporine genera by elongate dodecahedral oocysts, without equatorial faces, that are hexagonal in equatorial cross section with equatorial and terminal spines. The epimerite is very broadly ovoid and truncated posteriorly with equatorial lobiform tumidi that are posteriorly bilobate and do not form hooks, spines, or digitiform processes. The epimerite is borne on a long, slender stalk. The new species is also reported from naiads of Argia bipunctulata and adults and naiads of Enallagma civile(Odonata: Zygoptera).

Septate gregarines have been reported from both odonate naiads and adults (e.g., Ellis, 1913, 1914; Devdhar and Deshpande, 1971; Åbro, 1974, 1976, 1987; Richardson and Janovy, 1990). Of the 274 gregarine species described in Actinocephalidae, 36 species in 15 genera are reported from odonate hosts (Crawley, 1907; Watson, 1916; Levine, 1988; Richardson and Janovy, 1990). Odonate gregarines have been reported from all 3 subfamilies of Actinocephalidae; however, North American species are known only from 3 genera in 2 subfamilies: Geniorhynchus and Actinocephalus in Actinocephalinae and Prismatospora in Acanthosporinae. The third subfamily, Menosporinae, is dominated by gregarines reported from odonates (16 of 18 known species). The general paucity of the known North American gregarine fauna and the lack of known North American menosporid species suggest the existence of substantial unknown fauna.

During a taxonomic survey of the gregarine parasites of odonates in the Salt Valley of southeastern Nebraska, a distinct gregarine form was collected consistently from Argia bipunctulata (Zygoptera: Coenagrionidae). The secondary cuspidiform epimerite structure resembled that of Prismatospora evansi Ellis, 1914. However, a complete life cycle study revealed a unique group of morphological characters including a lobose, unhooked primary epimerite and spined, polyhedral oocysts without equatorial faces. The unique form of these structures prompted the present proposal of a new genus and species of eugregarine.

Received 13 November 1992; revised 16 February 1993; accepted 6 March 1993.

\section{MATERIALS AND METHODS}

Adult damselflies were isolated abdomen down in 5-ml capped plastic test-tubes with $1 \mathrm{ml}$ water for fecal collection. Twenty-four hours later each tube was examined for gregarine gametocysts. Shed gametocysts were freed from feces, pipetted with $10 \mu \mathrm{l}$ of water into individual wells of an HL-A tissue culture plate (Lux Scientific Corporation, Newbury Park, California), measured, and held for maturation and dehiscence.

Oocyst structure and dimensions were taken from fresh preparations of oocysts suspended in water. Oocysts rotated freely, allowing elucidation of the full 3-dimensional structure of the oocyst. Oocyst lengths, widths, and depths were measured at their widest points and are reported in micrometers. Clopton et al. (1991, 1992) demonstrated the utility of glycerin-based oocyst preparations. In the present study, however, oocysts collapsed in glycerin or Hoyer's medium-based preparations, suggesting oocyst structural instability under high osmotic tension. After cyst collection, damselflies were dissected in insect saline without sucrose (Belton and Grundfest, 1962) and examined for parasites. Sixty-nine of 119 damselflies examined between July and September 1992 were infected. Measurements were taken on no more than 5 individuals per host. Widths of protomerites and deutomerites were taken at the widest points.

Measurements are presented as range values followed by means, standard deviations, and sample sizes in parentheses. All measurements are in micrometers.

Levine's (1971) uniform terminology for Apicomplexa is used in this paper with a single exception. "Sporont" is used to indicate a mature individual that remains attached to the host intestine, in contrast to a gamont (a mature individual that is not attached to the host intestine and has formed an association) or to a trophozoite (an immature, vegetative individual that is attached to the host intestine). Terminology for shapes of planes is consistent with that suggested by the Systematics Association Committee for Descriptive Biological Terminology (Anonymous, 1962a, 1962b) and forms the basis for derivation of terminology for shapes of solids used in this description.

Drawings were made with the aid of a camera lucida. All observations were made on a Wild binocular com- 
pound microscope with $12.5 \times$ wide field eyepieces and American Optical-Spencer $10 \times$ and $40 \times$ objectives. Measurements and color observations in living specimens were made over blue and daylight filters, respectively.

\section{DESCRIPTION}

\section{Nubenocephalus n. gen.}

Diagnosis: Eugregarinida Léger, 1900, sensu Levine, Corliss, Cox, Deroux, Grain, Honigberg, Leedale, Loeblich, Lom, Lynn, Merinfeld, Page, Poljansky, Sprague, Vavra, and Wallace, 1980; Septatina Lankester, 1885, sensu Levine, Corliss, Cox, Deroux, Grain, Honigberg, Leedale, Loeblich, Lom, Lynn, Merinfeld, Page, Poljansky, Sprague, Vavra, and Wallace, 1980; Actinocephalidae Léger, 1892; Acanthsporinae Léger, 1892. Oocysts dodecahedral, elongate, terminally truncate, hexagonal in equatorial cross section, without equatorial faces, with equatorial and terminal spines. Epimerite broadly ovoid, truncated posteriad, with broad, flexible, equatorial tumidi that do not form hooks, spines, or digitiform processes; borne on a long slender stalk.

\section{Taxonomic summary}

Type species: Nubenocephalus nebraskensis $\mathrm{n} . \mathrm{sp}$.

Etymology: The generic name is given to mark the veiling nature of the crateriform protomerite of the type species.

\section{Remarks}

Actinocephalidae has been reviewed recently as part of a larger work (Levine, 1988). The new genus clearly is a member of Acanthosporinae in that spined oocysts are unique to this subfamily. Oocyst structure is distributed across the 20 genera that constitute Acanthosporinae as follows: 4 genera with polyhedral oocysts, 9 with biconical, 4 with ellipsoidal or ovoidal, 2 with unique asymmetrical oocysts, and 3 genera for which the oocysts are unknown (Tschudovskaia, 1928; Devdhar and Amoji, 1978; Kori and Amoji, 1985; Levine, 1988; Cokendolpher, 1991). Of the 4 described genera possessing polyhedral oocysts, the oocyst structure of the new genus resembles only that of the monotypic Prismatospora. However, the new genus is distinguished by lack of equatorial oocyst faces.

There has been no complete revision of Acanthosporinae and Devdhar and Amoji (1978) considered only epimerite and oocyst structure in their review of characters diagnostic among 12 member genera. Epimerite structure varies greatly among genera and among species within a single genus (Baudoin, 1971; Hoshide, 1977; Devdhar and Amoji, 1978). The broad range of variation among oocyst and epimerite structure within Acanthosporinae has led to generic distinctions based on cooccurrence of oocyst and epimerite structural types. Although the new genus is distinguished upon oocyst morphology alone, the epimerite structure of the new genus is unknown among the 4 described acanthosporinid genera possessing polyhedral oocysts.

\section{Nubenocephalus nebraskensis n. sp.}

$$
\text { (Figs. 1-6) }
$$

Trophozoite (Figs. 1, 2): Attached to host ventricular epithelium, solitary. Protomerite broadly obvoid to depressed obvoid; protomerite length (LP) 91.3$348.6(223.1,65.9 \pm, 66)$, protomerite width (WP)

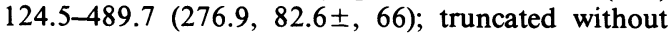
constriction at union with deutomerite, becoming crateriform anteriad in late trophozoites. Deutomerite broadly obvoid in very young trophozoites, narrowly obvoid in late trophozoites; deutomerite length (LD) 141.1-1,651.7 (858.92, 321.4, \pm 66$)$, deutomerite width (WD) 116.2-481.4 (257.1, 86.3 4 , 66); distended anteriad at union with protomerite. Total length (TL) 340.3-2,000.3 (1,082.0, 363.6, \pm 66$)$; LP/TL 0.13-0.59 (0.22, 0.08, \pm 66$) ;$ LD/TL $0.41-0.87(0.78,0.08 \pm, 66)$; LP/LD 0.14-1.41 (0.31, 0.22, \pm 66$)$; WP/WD 0.32$1.44(1.11,0.20 \pm, 66)$. Epimerite borne on a narrow basal stalk; length $20.0-54.0(34.4,8.6 \pm$, 54), width $10.0-16.0(12.9,1.7 \pm, 54)$. Epimerite very broadly ovoid; length $22.0-46.0(34.0,5.5 \pm, 54)$, width 30.0 $48.0(37.0,5.1 \pm, 54)$; truncate posteriad at union with epimerite stalk, with 6 equatorial lobiform tumidi; tumidi posteriorly bilobate and not forming hooks, spines, or digitiform processes. Epimerite without visible septum; obvious in young trophozoites, apparent in some form in most trophozoite stages. Total epimerite length $46.0-100.0(68.4,11.63 \pm, 54)$. Nucleus narrowly elliptoid to elliptoid; length 50.0-88.0 (69.1, $9.3 \pm, 52)$, width $20.0-42.0(36.1,5.2 \pm, 52)$; placement consistent, abaxial, and supraequatorial. Nuclear endosomes variable in shape and number. Fresh trophozoites with endocyte partially granular when very young, becoming opaque with maturity, epicyte clear to light orange in color; width $8.0(8.0,0.0 \pm, 66)$. Whitish under dissecting microscope and incandescent illumination, brown under compound microscope and daylight filter.

Sporont (Fig. 3): Attached to host ventricular epithelium, solitary. Protomerite very broadly obvoid to depressed obvoid; LP 157.7-597.6 (280.1, 110.1 \pm , 54), WD 249.0-871.5 (434.7, 155.4 \pm , 54); truncated with constriction at union with deutomerite; anterior margins uncleft, expanded to form a broad, crateriform adhesive disk; apex distended to contact the host epithelium. Anterior margins of protomerite in late sporonts cleft or folded, becoming corollate with 2 narrow ventral lobes and 1 broad dorsal lobe. No epimerite observed; transitional forms possess remnants of epimerite stalk. Deutomerite obvoid to narrowly obvoid; LD 506.3-2,672.6 (1,279.7, 458.2 \pm , 54), WD 190.9846.6 (391.6, 156.6 \pm , 54); TL 713.8-3,237.0 (1,559.8, $554.3 \pm, 54) ; \mathrm{LP} / \mathrm{TL} 0.12-0.29(0.18,0.04 \pm, 54)$; LD/ TL $0.71-0.88(0.82,0.04 \pm, 54)$; LP/LD 0.14-0.41 (0.22,

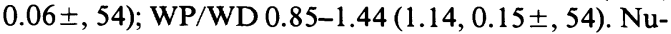

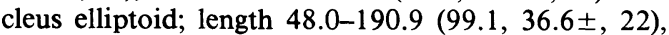
width $28.0-116.2(56.4,22.3 \pm, 22)$; placement consistent among individuals and developmental stages, abaxial and supraequatorial in deutomerite. Nuclear endosomes variable in shape and number. Fresh sporonts with granular endocyte, nonuniform and opaque with clear epicyte; width 5.0-8.3 (7.0, 1.62 \pm , 30). Whitish under dissecting microscope and incandescent light, translucent brown to opaque black under compound microscope and daylight filter.

Gamont (Fig. 4): Partially to completely enrobed in host ventricular peritrophic membrane, solitary or in association. Protomerite transversely broadly elliptoid; LP 174.3-597.6 (351.4, 124.6 \pm , 24), WP 439.9-871.5 $(564.4,145.8 \pm, 24)$; apex smooth, no evidence of cra- 

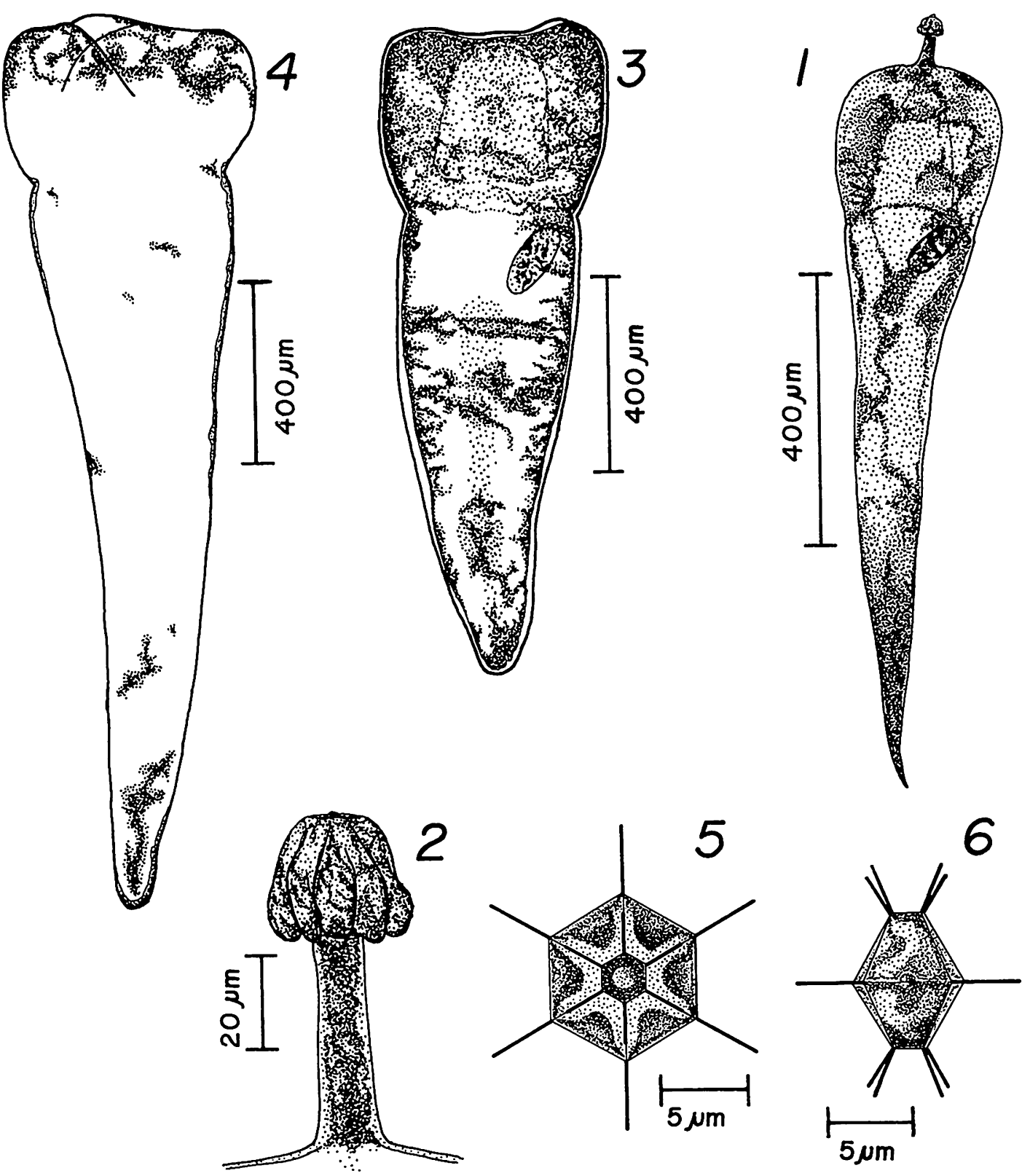

Figures 1-6. Nubenocephalus nebraskensis n. gen., n. sp. 1. Trophozoite, lateral view. 2. Primary epimerite of trophozoite, lateral view. 3. Sporont, lateral view. 4. Mature gamont with disassociated nucleus, lateral view. 5. Oocyst, dorsal aspect. 6. Oocyst, lateral aspect. (Shallow depth of field and diffraction of lateral faces give the illusion of reduced equatorial width, reproduced here to facilitate diagnosis.)

teriform margin observed. Deutomerite obvoid to narrowly obvoid; LD 888.1-2,672.6 (1,590.8, 490.8 4 , 24), WD $356.9-846.6(525.67,139.4 \pm, 24)$; TL $1,062.4$ $3,237.0(1,942.2,603.2 \pm, 24) ;$ LP/TL $0.15-0.24(0.18$, $0.03 \pm$, 24); LD/TL $0.76-0.85$ (0.82, 0.03 \pm , 24); LP/ LD $0.17-0.31(0.22,0.04 \pm, 24)$; WP/WD $0.98-1.28$ $(1.08,0.09 \pm, 24)$. Nucleus diffuse and indistinct. Fresh gamonts with opaque endocyte, no distinct epicyte ob- served. White under dissecting microscope and incandescent light, translucent to opaque black under compound microscope and daylight filter.

Association: Syzygy late and ephemeral, latero-associative while caudally enrobed in peritrophic membrane. Sporont to gamont transformation marked by loss of anterior crateriform adhesive disk and an anteriad rounding of the protomerite, dissolution of the 
nucleus, and a general shift from translucence to opaqueness. Syzygy begins as 2 adjacent sporonts fuse caudally. Fusion line progresses anteriad to produce association. Association similar in form and length to, but broader than, single sporont. Association folds over on itself in roughly equal thirds producing single membrane-bound gametocyst. Internal association membranes lost during gamete production. Gametocysts often shed before loss of internal association membranes and development continues exogenously. Associations observed in the posterior quarter of ventriculus. Observations suggest that associations that have not completed syzygy and initiated formation of the gametocyst membrane do not survive passage through the rectum.

Gametocyst: Opalescent and spherical; diameter 420.0-640.0 (532.6, 67.5 1 , 19); hyaline coat uniform, increasing diameter to $920.0-1,270.0(1,032.6,107.8 \pm$, 19). Gametocysts collected and stored under (ca. $22 \mathrm{C}$ ) water sporulate by dehiscence between 60 and $72 \mathrm{hr}$.

Oocyst (Figs. 5, 6): Oocysts dodecahedral; axial length $7.84(7.84,0 \pm, 46)$, equatorial width $9.8(9.80,0 \pm$, 46) (shallow depth of field and diffraction of lateral faces give the illusion of an apparent width of ca. 4.9 [Fig. 6]); elongate, terminally truncate; terminal width $1.47(1.47,0 \pm, 46)$; hexagonal in equatorial cross section, with 6 equatorial spines; length 3.92 (3.92, $0 \pm$, 46); 1 spine at each equatorial angle and 12 terminal spines; length $2.94(2.94,0 \pm, 46) ; 1$ spine at each terminal angle. Each oocyst has an equatorially located spherical residuum; diameter $1.25(1.25,0 \pm, 46)$. Oocysts very uniform in size and shape.

\section{Taxonomic summary}

Type host: Argia bipunctulata (Zygoptera: Coenagrionidae).

Host records: Argia bipunctulata naiads and adults; Enallagma civile (Zygoptera: coenagrionidae) naiads and adults.

Type locality: Bowling Lake (Section 2, Township 10 North, Range 6 East), Lancaster County, Nebraska.

Specimens deposited: Two (1 trophozoite, 1 sporont) type slides have been deposited in the United States National Museum Helminthological Collection, Biosystematic Parasitology Laboratory, Beltsville, Maryland. The trophozoite (USNM Helm. Coll. No. 82671 ) is the holotype and clearly demonstrates characteristic primary epimerite structure; however, the sporont (USNM Helm. Coll. No. 82672) clearly demonstrates the more typical mature body shape and secondary anterior crateriform margin and should be considered in any revision.

Infection site: Trophozoites were observed in the anterior $2 / 3$ of the ventriculus, attached to the epithelium and outside the peritrophic membrane. Sporonts were observed in the lower $1 / 2$ of the ventriculus, attached to the epithelium and outside the peritrophic membrane. Gamonts were observed in the lower $1 / 3$ of the ventriculus, caudally enrobed in the peritrophic membrane.

Etymology: The specific name nebraskensis is given to mark the type locality and to mark the 100th anniversary of parasitology research and curriculum at the University of Nebraska.

\section{Remarks}

In 2 other genera, the monotypic Prismatospora and several species within the Ancyrophora, transmutation of the primary epimerite to a larger cuspiform structure has been reported (Ellis, 1914; Hoshide, 1977). All known cases of epimerite transmutation occur in species described or reported only from odonates. Ellis (1914) suggested that this transformation may serve to anchor the parasite during the violent displacements of the intestine associated with the rectal gill movements characteristic of immature anisopterans; however, the same transmutation is observed in parasites of adult anisopterans and in adult and immature zygopterans.

\section{ACKNOWLEDGMENTS}

This work was supported in part by Ashton C. Cuckler and U. S. Harkson fellowships awarded to R.E.C.

\section{LITERATURE CITED}

ÅBRO, A. 1974. The gregarine infection in different species of Odonata from the same habitat. Zoologica Scripta 3: 111-120.

- 1976. The mode of gregarine infection in Zygoptera (Odonata). Zoologica Scripta 5: 265275.

- 1987. Gregarine infection of Zygoptera in diverse habitats. Odonatologica 16: 119-128.

ANONYMOUS. 1962a. Systematics Association Committee for Descriptive Biological Terminology. II. Terminology of simple symmetrical plane shapes (Chart 1). Taxon 11: 145-155.

- 1962b. Systematics Association Committee for Descriptive Biological Terminology. IIa. Terminology of simple symmetrical plane shapes (Chart 1a). Taxon 11: 245-247.

BAUDOIN, J. 1971. Etude comparée de quelques grégarines Acanthosporinae. Journal of Protozoology 18: 654-660.

Belton, P., AND H. Grundfest. 1962. Potassium activation and $\mathrm{K}$ spikes in muscle fibers of the mealworm larva (Tenebrio molitor). American Journal of Physiology 203: 588-594.

Clopton, R. E., T. J. Percival, AND J. Janovy, JR. 1991. Gregarina niphandrodes n. sp. (Apicomplexa: Eugregarinorida) from adult Tenebrio molitor (L.) with oocyst descriptions of other gregarine parasites of the yellow mealworm. Journal of Protozoology 38: 472-483.

$\longrightarrow, \longrightarrow$, AND 1992. Gregarina cuneata n. sp. (Apicomplexa: Eugregarinida) described from adults of the southern corn rootworm, Diabrotica undecimpunctata howardi (Coleoptera: Chrysomelidae). Journal of Protozoology 39: 417-420.

COKENDOLPHER, J. C. 1991. Cosmetophilus vonones, n. g., n. sp. (Apicomplexa: Actinocephalidae) in the harvestman Vonones sayi (Arachnida: Cosmetidae). Journal of Protozoology 38: 461-464.

Crawley, H. 1907. The polycystid gregarines of the United States (third contribution). Proceedings of 
the Academy of Natural Sciences of Philadelphia 59: 220-228.

Devdhar, M. J., AND S. D. Amoji. 1978. On a new actinocephalid gregarine, Contospora opalnia gen. nov., sp. nov. from the gut of an arachnid Opalnia sp. Archiv für Protistenkunde 120: 182-189. , AND S. DESHPANDE. 1971. On a new gregarine Menospora nonacantha, n. sp., from the odonate Agriocnemis sp. (fam. Coenagriidae) from Dharwar, India. Indian Zoologist 2: 41-54.

Ellis, M. 1913. A descriptive list of the cephaline gregarines of the New World. Transactions of the American Microscopical Society 32: 259-296.

- 1914. An acanthosporid gregarine from North American dragonfly nymphs. Transactions of the American Microscopical Society 33: 215-222.

HoshIDE, K. 1977. Notes on the gregarines in Japan 8: Three new species of Eugregarina from Odonata. Bulletin of the Faculty of Education, Yamaguchi University 27: 93-125.
KORI, S. S., AND S. D. AmojI. 1985. Tetrameridionospinispora karnataki, new genus new species: A new cephaline gregarine from the damselfly, Agriocnemis sp. Acta Protozoologica 24: 139-146.

LEVINE, N. D. 1971. Uniform terminology for the protozoan subphylum Apicomplexa. Journal of Protozoology 18: 352-355.

1988. The protozoan phylum Apicomplexa, Vol. I. Chemical Rubber Company Press, Boca Raton, Florida, 203 p.

Richardson, S., AND J. JANOVY, JR. 1990. Actinocephalus carrilynnae n. sp. (Apicomplexa: Eugregarinorida) from the blue damselfly, Enallagma civile (Hagen). Journal of Protozoology 37: 567-570.

TschudovsKaIA, I. 1928. Uber einige Parasiten aus dem Darmkanal der Sciara-larven. Archiv für Protistenkunde 60: 287-304.

WATSON, M. E. 1916. Studies on gregarines. Illinois Biological Monographs 2(3): 1-258. 